ISSN 0258-7122 (Print), 2408-8293 (Online)

Bangladesh J. Agril. Res. 42(3): 413-424, September 2017

\title{
PRODUCTION POTENTIAL AND ECONOMICS OF MUNG BEAN IN RICE BASED CROPPING PATTERN IN SYLHET REGION UNDER AEZ 20
}

\author{
M. I. NAZRUL ${ }^{1}$, M. K. HASAN ${ }^{2}$ AND M. R. I. MONDAL ${ }^{3}$
}

\begin{abstract}
The study was conducted at the farmers field in Sylhet under AEZ 20 during three consecutive years 2012-13, 2013-14 and 2014-15 to determine the productivity and profitability of cropping patterns viz., IP: improved pattern (Mung bean-T. aus-T. aman rice) and FP: farmer's pattern (Fallow-T. aus-T. aman rice) through incorporation of high yielding varieties and improved management practices. The experiment was laid out in randomized complete block design with six dispersed replications. Results showed that the improve pattern with management practices provided 10.85 and $14.32 \%$ higher grain yield of T. aus and T. aman rice, respectively; also contributed more T. aman mean rice equivalent yield $\left(11.81 \mathrm{t} \mathrm{ha}^{-1}\right)$ compared to farmer's pattern. Mean sustainable yield index (77.63\%), production efficiency $\left(47.88 \mathrm{~kg} \mathrm{ha}^{-1} \mathrm{day}^{-1}\right)$, and land use efficiency $(67.66 \%)$ were maximum in Mung bean-T. aus- T. aman rice cropping system. Similarly, the highest mean gross margin (Tk.126762 ha-1) with benefit cost ratio (2.10) was obtained from improved pattern. Three years results revealed that $42 \%$ extra cost provides an ample scope of considerable improvement of the productivity of improved pattern with the inclusion of Mungbean before $T$. aus rice.
\end{abstract}

Keywords: Agronomic performance, land use efficiency, production potential, sustainable yield index, fallow land utilization

\section{Introduction}

In Sylhet region, mainly Fallow - T. aus - T. aman rice cropping pattern is widely followed by farmers under rainfed condition. Transplantation of aus rice is being dependant on rainfall, which sown during early monsoon (early May). This delayed transplantation of $\mathrm{T}$. aus rice that causes late cultivation and harvesting of T. aman rice, which hampered timely cultivation of rabi crops; so, winter crops are not possible to be grown. The soils under these cropping pattern areas are generally heavy silty clay loams to clays and the top soil quickly becomes dry and hard after the harvest of T. aman rice. In Eastern Surma Kushiara Floodplain of Sylhet region, a vast area remains fallow for a long time after the harvest of $\mathrm{T}$. aman rice due to moisture stress up to next season for cultivation of $\mathrm{T}$. aus rice following the existing cropping pattern (Fallow-T. aus-T. aman rice). However, the yields of rice are very low compared to other regions of the country. Farmers

${ }^{1}$ Senior Scientific Officer, ${ }^{2}$ Principal Scientific Officer, On-Farm Research Division, ${ }^{3}$ Ex-Director General, Bangladesh Agricultural Research Institute (BARI), Gazipur-1701, Bangladesh. 
try to improve crop productivity through addition of chemical fertilizers but, chemical fertilizers are expensive and generally cannot afford to buy many poor farmers. Higher crop productivity can also be achieved through the use of organic fertilizers such as compost or farmyard manure and recycling of crop and organic residues in production systems which can improve soil health. Nevertheless, lack of available organic fertilizers and high transport cost are major constraints. Consequence of this scenario, incorporation of legumes into the existing cropping systems seems to be a logical approach. Legumes are known to biologically fix atmospheric nitrogen $(\mathrm{N})$ in symbiosis with Rhizobium bacteria. This can partly reduce the $\mathrm{N}$ fertilizer requirement of the main field crop in rotation. Thus it becomes a modest source of $\mathrm{N}$ for resource-poor farmers (McDonagh et al., 1995). Inclusion of grain legumes plays an important role for increasing cropping intensity or even sustaining crop productivity along with improving nutritional status of the people and maintaining soil health (Becker et al., 1995; Norman et al., 1984).

Generally, rainfall starts in February and prevails up to November in each year that offers an excellent opportunity for the production of short duration pulse crops before T. aus rice. Nazrul and Shaheb (2012b) reported that pulse crops can be grown well in fallow land of Sylhet where mungbean (var. BARI Mung-6), chickpea (var. BARI Chola-5) and lentil (var. BARI Mosur-6) could be more suitable and produced higher seed yield. To enhance the crop production through utilization of fallow land in Sylhet region, the potato-rice and chickpea-rice based cropping patterns have been developed (Nazrul et al., 2013; Nazrul and Shaheb, 2012a; Shaheb et al., 2011).

A number of reports on different cropping pattern are available in Bangladesh and India that an additional crop could be introduced without much changes or replacing the existing ones for considerable increases of productivity as well as profitability of the farmers (Azad et al., 1982; Malavia et al., 1986; Soni and Kaur, 1984; Khan et al., 2005; Nazrul et al., 2013, Kamrozzaman et al., 2015). But, little effort has been made for on-farm evaluation of the improved technologies of Mungbean-T. aus-T. aman rice cropping pattern in Sylhet area. The present study was therefore, initiated with a view to determine productivity and economic feasibility of an improved package of technologies over the farmer's existing practices.

\section{Materials and Method}

The study was carried out during three consecutive years 2012-13, 2013-14 and 2014-15 at farmer's field, Sylhet (24 $54^{\prime} \mathrm{N}$ latitudes and 91 ${ }^{\circ} 58^{\prime} \mathrm{E}$ longitude) located in Agro Ecological Zone (AEZ)-20; under Eastern Surma Kushiyara Floodplain. This trial was conducted to derive the economic consequences of two cropping patterns viz. IP: improved pattern (Mungbean-T. aus-T. aman) and FP: farmer's pattern (Fallow-T. aus-T. aman) through incorporation of high yielding varieties and improved management practices. 
Annual monthly total rainfalls, along with maximum and minimum average temperatures during the study period are presented in Fig. 1. The highest amount of average monthly rainfall occurred in June followed by August, July and May, whereas lowest amount of rainfall occurred in January followed by December and February. Rainfall increases gradually from the month of January to June and then decreases. The crops received 3765,3938 and $3760 \mathrm{~mm}$ total rainfall during crop season of 2012-13, 2013-14 and 2014-15, respectively. The monthly mean maximum air temperature was $30.33,31.24$ and $30.31{ }^{\circ} \mathrm{C}$ and minimum 20.83 , 20.77 and $20.62{ }^{\circ} \mathrm{C}$ during the crop season of 2012-13, 2013-14 and 2014-15, respectively.

The soil was clay loam with low organic matter content $(1.63 \%)$ and soil $\mathrm{pH}$ ranged from 4.10 to 5.63 acidic in nature. The initial status of $\mathrm{N}(0.07 \%), \mathrm{P}(7.59$ $\mu \mathrm{g} / \mathrm{soil}), \mathrm{K}(0.18 \mathrm{meq} / 100 \mathrm{~g}$ soil $), \mathrm{S}(10.80 \mu \mathrm{g} / \mathrm{soil}), \mathrm{B}(0.34 \mu \mathrm{g} / \mathrm{soil})$ and $\mathrm{Zn}(1.27$ $\mu \mathrm{g} / \mathrm{soil})$ was very low, low, low, low, medium and medium, respectively. The trial was laid out in randomized complete block design with six dispersed replications. Two plots of $500 \mathrm{~m}^{2}$ were selected for each replication. One plot was under the improved pattern and the other farmer's pattern.

In the improved pattern, mung bean var. BARI Mung- 6 was introduced against fallow period. The T. aus rice var. BRRI dhan 48 and T. aman rice var. Binadhan7 was introduced instead of BR-26 and BRRI dhan33, respectively. The agronomic parameters and cultural operation for crop production under improved and farmer's practices are presented in Table 1. All field operation and management practices of both farmer's and improved pattern were closely monitored and the data were recorded for agro-economic performance. The differences between mean was compared by t-test.

Agronomic performance viz., land use efficiency, production efficiency, rice equivalent yield and sustainable yield index of cropping patterns were calculated. Land use efficiency is worked out by taking total duration of individual crop in a sequence divided by 365 days (Tomer and Tiwari, 1990). It is calculated by following formula:

Land use efficiency $=\frac{\mathrm{d}_{1}+\mathrm{d}_{2}+\mathrm{d}_{3}}{365} \times 100$

Where $d_{1}, d_{2}$ and $d_{3}$ the duration of first, second and third crops of the pattern.

Production efficiency: Production efficiency values in terms of $\mathrm{Kg} \mathrm{ha}^{-1} \mathrm{day}^{-1}$ were calculated by total production in a cropping sequence divided by total duration of crops in that sequence (Tomer and Tiwari. 1990).

Production efficiency $=\frac{\mathrm{Y}_{1}+\mathrm{Y}_{2}+\mathrm{Y}_{3}}{\mathrm{~d}_{1}+\mathrm{d}_{2}+\mathrm{d}_{3}}\left(\mathrm{Kg} \mathrm{ha}^{-1} \mathrm{day}^{-1}\right)$

Where, $Y_{1}$ : Yield of first crop; and $d_{1}$ : Duration of first crop of the pattern; $Y_{2}$ : Yield of second crop and $\mathrm{d}_{2}$ : Duration of second crop of the pattern; $\mathrm{Y}_{3}$ : Yield of third crop and $\mathrm{d}_{3}$ : Duration of third crop of the pattern. 
Sustainable Yield index (SYI) was worked out by the following formula suggest by Krishna and Reddy (1997).

Sustainable yield index $=\frac{\mathrm{Y}_{\text {mean }} \mathrm{SD}}{\mathrm{Y}_{\max }} \times 100$

Where, $\mathrm{Y}_{\text {mean }}$ : Estimated mean yield of a practice over years; SD: Estimated standard deviation; $\mathrm{Y}_{\max }$ : Observed maximum yield in the experiment over the years.

\section{Rice equivalent yield:}

For comparison between crop sequences, the yield of all crops was converted into rice equivalent yield (REY) on the basis of prevailing market price of individual crop (Verma and Modgal, 1983).

Rice equivalent yield $\left(\mathrm{t} \mathrm{ha}^{-1}\right)=\frac{\text { Yield of individual crop } \times \text { Market price of that crop }}{\text { Market price of rice }}$

The economic indices like gross and net returns and benefit cost ratio were also calculated on the basis of prevailing market price of the produces. For economic evaluation of two different cropping sequences averaged data of two crop cycles were used. The gross cost of cultivation of different crops was calculated on the basis of different operations performed and materials used for raising the crops. Benefit cost ratio (BCR) was also calculated by the following formula:

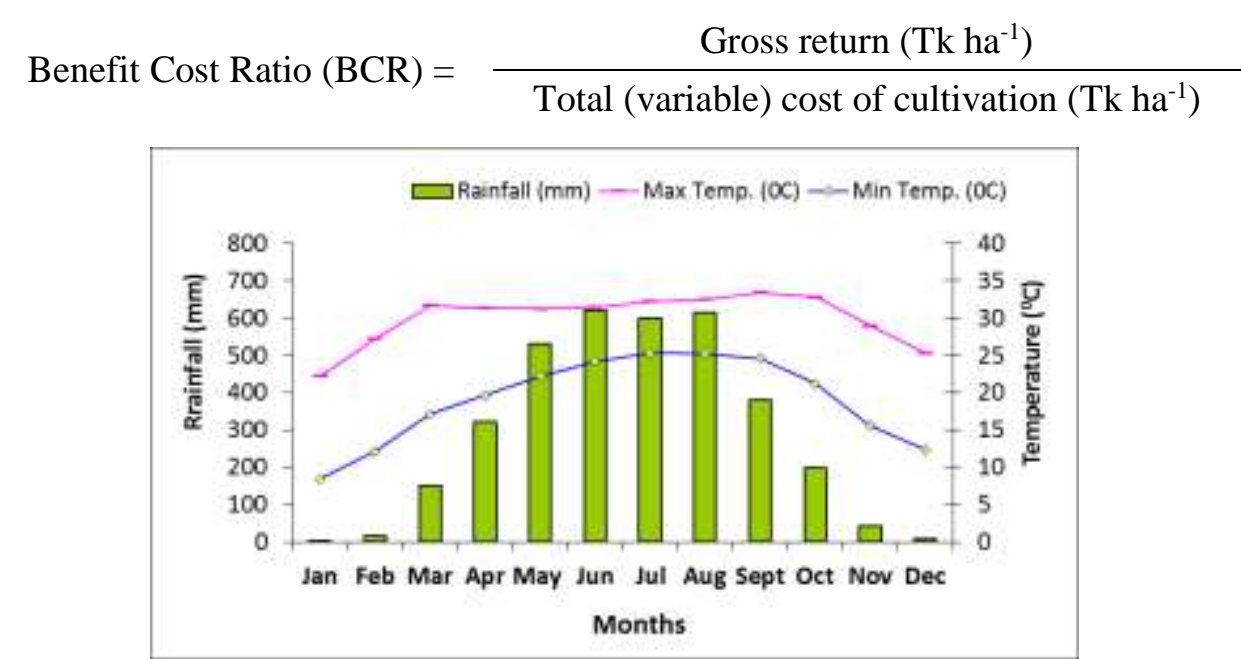

Fig. 1. Average of three years monthly total rainfall $(\mathrm{mm})$, maximum and minimum air temperatures during study period (Source: Metrological Department, Sylhet). 
PRODUCTION POTENTIAL AND ECONOMICS OF MUNG BEAN

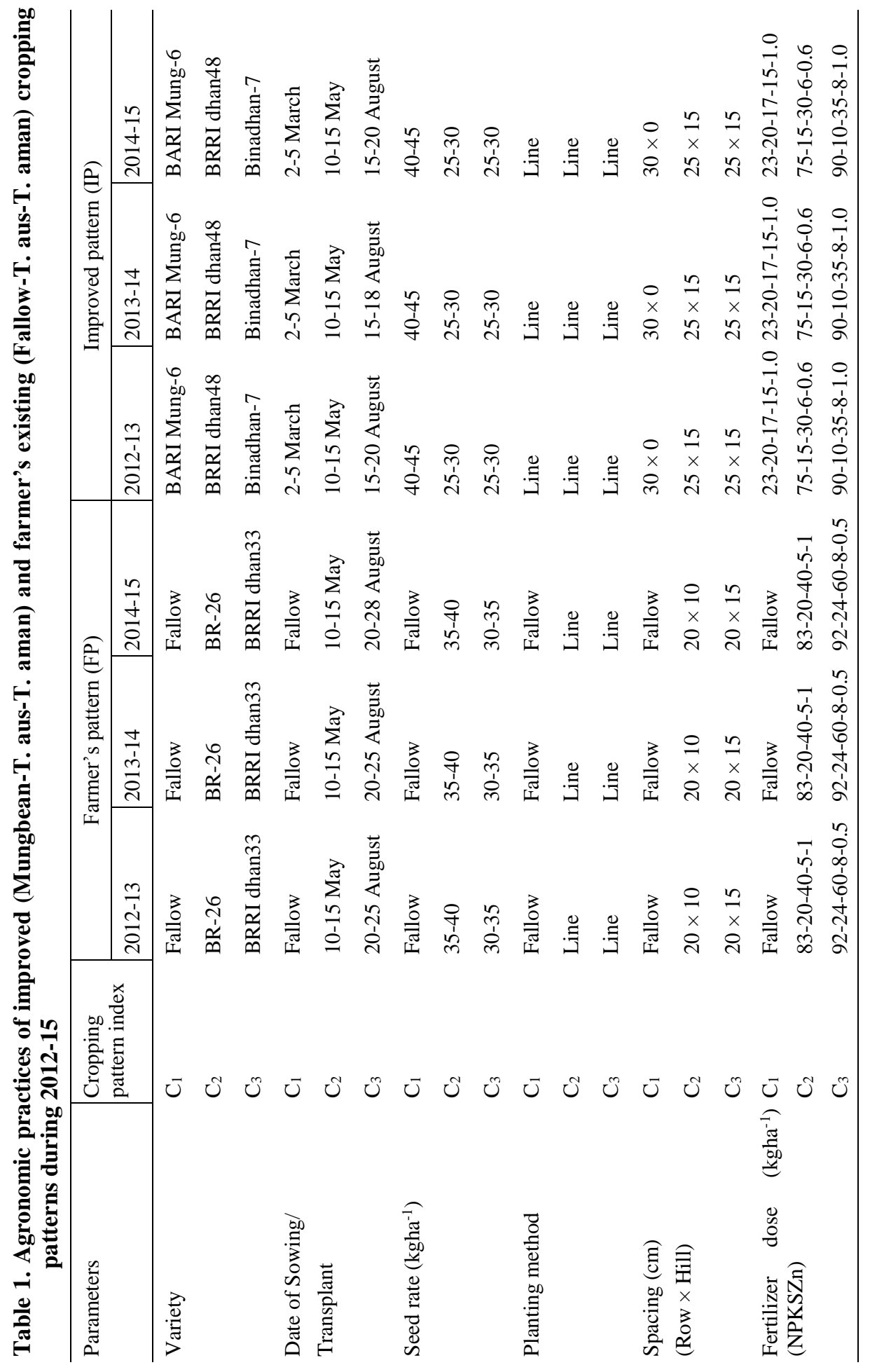




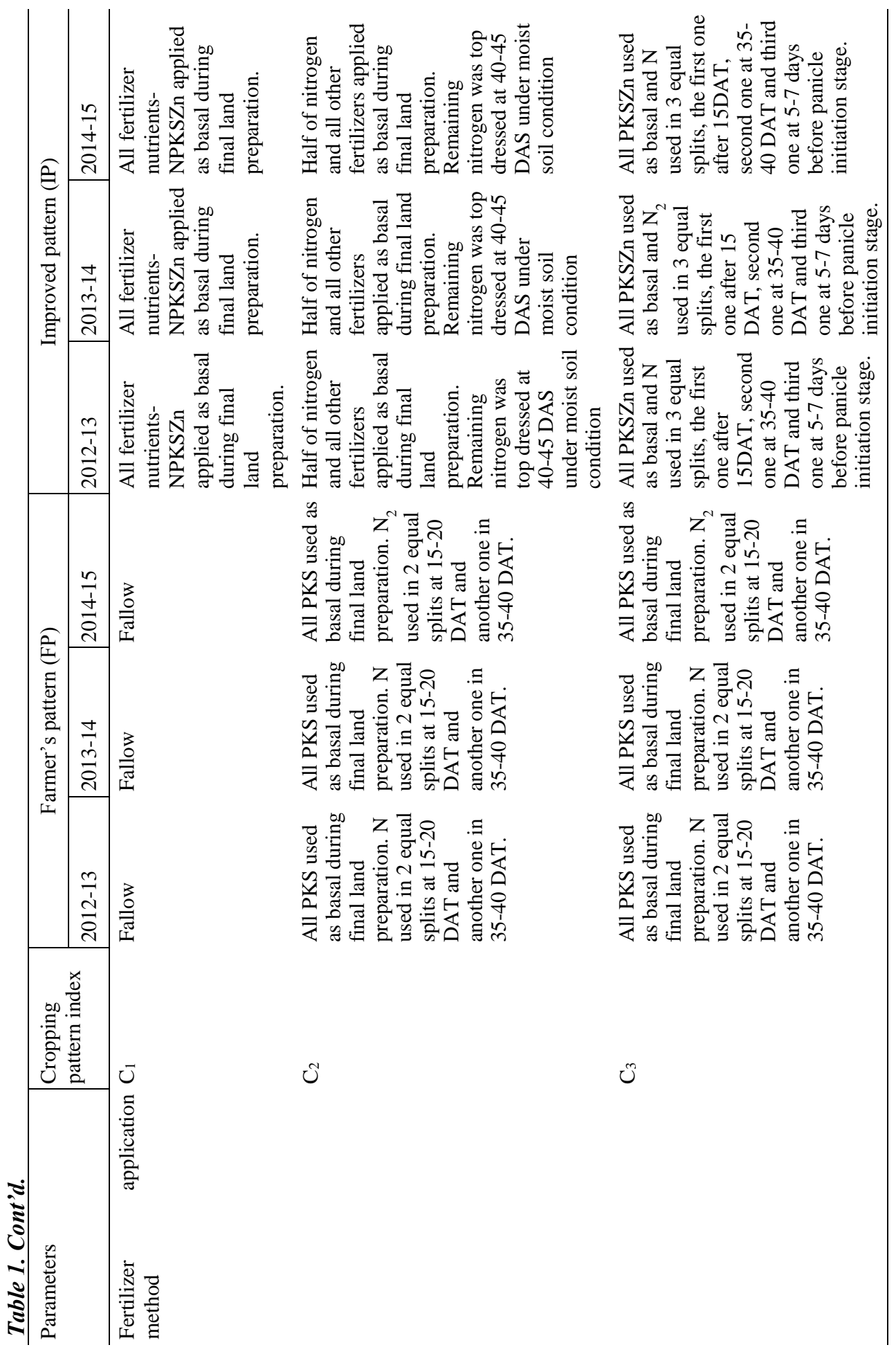




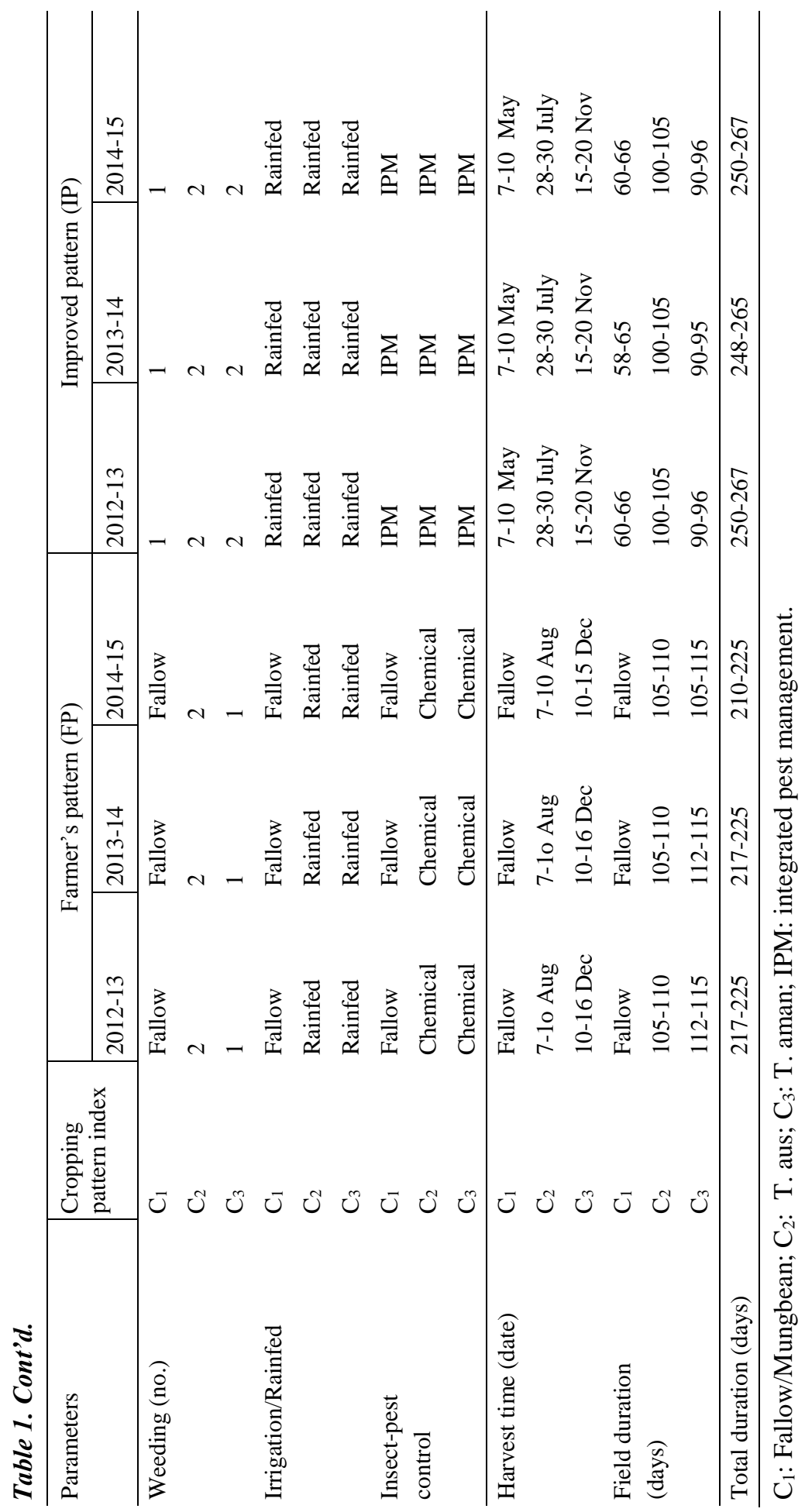




\section{Results and Discussion}

\section{Grain/Seed Yield of the Cropping Patterns}

Improved pattern took 249-266 days against 214-225 days due to inclusion of mungbean in the pattern. This indicates that mungbean could easily be grown or fitted before $T$. aus rice. The yield of rice was significantly higher in the improved pattern as compared to farmers existing pattern during individual years and also in mean data (Table 2). Variation in the yield of rice as evident in the improved pattern might be due to change of variety with improved production technologies. Similar results were also obtained by Nazrul et al. (2013) and Khan et al. (2005) in case of rice based cropping sequences. In all the years, farmers' pattern gave lower grain yield of rice due to imbalance use of fertilizers and traditional management practices. But in year of 2012-13, the yield of T. aus rice was little lower in improved pattern due to partial lodging. Furthermore in year of 2014-15, the yield of T. aman rice was also insignificantly lower in improved pattern compared to farmer's pattern due to attack of rice bug at panicle formation to flowering. Chlorpyrifos insecticide (Dursban 20 EC @ $20 \mathrm{ml}$ in 10 liters of water for 5 decimal areas) was sprayed for controlling this pest. The rice variety, Binadhan-7 in improved pattern performed better than BRRI dhan33 in farmers' practices due to higher yield potential of the variety.

\section{By-product yield of the cropping patterns}

The improved cropping pattern produced higher amount of total by-product yield $\left(11.13\right.$ tha $\left.^{-1}\right)$ than the by-product yield of the crops $\left(9.03 \mathrm{t} \mathrm{ha}^{-1}\right)$ of the farmers' pattern (Table 2). The by-product yield of improved pattern was higher due to introduction and change of variety with improved technologies for the component crops. In all the years, mungbean contributed valuable by-product. On the contrary, farmers are not able to sale by-product (rice straw) in the local market; whereas, the by-product of mungbean can be used as green manure and incorporate in the field for soil health improvement.

\section{Rice equivalent yield}

The component crops of Mungbean-T. aus-T. aman rice cropping pattern under improved practices (IP) gave higher T. aman rice equivalent yields against grain yield as well as by-product in all the years. The mean rice equivalent yield under improved cropping pattern also produced higher rice equivalent yield over farmers' traditional cropping pattern (Table 3 ). On an average, the T. aman rice equivalent yield in improved pattern increased $73 \%$ over the crops under farmers' practices. Inclusion of high yielding new crop varieties with improved management practices increased the higher $\mathrm{T}$. aman rice equivalent yield. It was also due to higher price of components crops in the improved pattern. Lower rice equivalent yield was obtained in the farmers' pattern probably due to variety and traditional management practices. 


\section{Production efficiency}

Maximum production efficiency was obtained from improved pattern during individual years and also means data (Table 3 ). The higher production efficiency of improved cropping pattern might be due to inclusion of a new or modern varieties and management practices. In conversely, the lowest production efficiency was observed in farmers' pattern where crop remained in the field for shorter time and yields were also lower, leading to lower production per day. Mean production efficiency $\left(47.88 \mathrm{~kg} \mathrm{ha}^{-1} \mathrm{day}^{-1}\right)$ was higher in improved pattern and lower $\left(36.97 \mathrm{~kg} \mathrm{ha}^{-1} \mathrm{day}^{-1}\right)$ in farmers' pattern. Similar trend were noted by Nazrul et al. (2013) and Khan et al. (2005) in case of improved cropping sequences.

\section{Land use efficiency}

Land use efficiency is the effective use of land in a cropping year, which mostly depends on crop duration. The average land-use efficiency indicated that improved pattern used the land for $67.66 \%$ period of the year, whereas farmer's pattern used the land for $50.68 \%$ period of the year (Table 3). The land use efficiency was higher in improved pattern due to cultivation of mungbean as component crop in fallow period.

Table 2. Productivity of improved (Mungbean-T. aus-T. aman) and farmer's existing (Fallow-T. aus-T. aman) cropping patterns during 2012-15

\begin{tabular}{|c|c|c|c|c|c|c|c|}
\hline \multirow[b]{2}{*}{ Years } & \multirow{2}{*}{$\begin{array}{c}\text { Cropping } \\
\text { patterns }\end{array}$} & \multicolumn{3}{|c|}{ Seed/Grain yield $\left(\mathrm{t} \mathrm{ha}^{-1}\right)$} & \multicolumn{3}{|c|}{ By product yield $\left(\mathrm{t} \mathrm{ha}^{-1}\right)$} \\
\hline & & $\begin{array}{c}\text { Fallow/ } \\
\text { Mungbean }\end{array}$ & T. aus & T. aman & $\begin{array}{c}\text { Fallow/ } \\
\text { Mungbean }\end{array}$ & T. aus & T. aman \\
\hline \multirow[t]{2}{*}{$2012-13$} & FP & - & 3.25 & 3.75 & - & 4.36 & 4.79 \\
\hline & IP & 1.12 & 3.20 & 4.50 & 1.68 & 4.31 & 4.86 \\
\hline \multirow[t]{2}{*}{ 2013-14 } & FP & - & 3.51 & 3.64 & - & 4.40 & 4.51 \\
\hline & IP & 1.30 & 3.85 & 4.35 & 1.98 & 4.65 & 4.70 \\
\hline \multirow[t]{2}{*}{ 2014-15 } & FP & - & 3.47 & 3.70 & - & 4.37 & 4.65 \\
\hline & IP & 1.10 & 4.30 & 3.85 & 1.66 & 4.92 & 4.49 \\
\hline \multirow[t]{2}{*}{ Mean } & FP & - & 3.41 & 3.70 & - & 4.37 & 4.66 \\
\hline & IP & 1.17 & 3.78 & 4.23 & 1.77 & 4.62 & 4.74 \\
\hline
\end{tabular}

Note- FP: Farmer's pattern, IP: Improved patter;

The costs $\left(\mathrm{Tkkg}^{-1}\right)$ : rice seed (32.00), mungbean seed (150.00), and, urea (20.00), TSP (22.00) and MoP (15.00);

Among field operations, the cost of plowing was taken as Tk 10 decimal $^{-1}$, labour cost of $\mathrm{Tk} 300 \mathrm{~m}^{-1} \mathrm{day}^{-1}$. Gross returns included income from sale of main and by-products (Tk $\mathrm{ka}^{-1}$ ) of all crops; T. aus rice (19.00), T. aman rice (20.50), mungbean (70.00), stover (1.00). 


\section{Sustainable yield index}

The sustainable yield index (SYI) of farmer's and improved cropping pattern is presented in Table 3. The values of sustainable yield index as a measure of sustainability of the system which was high in the improved cropping system (66.88-95.72\%) over farmer's practices (63.55-76.63\%). The results showed that between two different cropping systems Mungean-T. aus-T. aman rice recorded the highest mean SYI of $77.63 \%$ followed by Fallow-T. aus-T. aman rice (70.10\%). So, cropping system involving mungbean in fallow period and modern varieties of T. aus and T. aman rice recorded higher SYI compared to fallow-rice based crop sequences. The results are in agreement with the findings of Nazrul et al. (2013) and Ram et al., (2012). This indicated that improved pattern is therefore, more stable than farmer's pattern. Mungbean is providing special advantage regarding utilization of fallow land and can improve the soil health.

Table 3. Rice equivalent yield, production efficiency, land use efficiency and sustainable yield index of improved and farmers patterns at farmer's field during 2012-15

\begin{tabular}{c|c|c|c|c|c}
\hline Years & $\begin{array}{c}\text { Cropping } \\
\text { patterns }\end{array}$ & $\begin{array}{c}\text { Rice (T. aman) } \\
\text { equivalent yield } \\
\left(\text { tha }^{-1}\right)\end{array}$ & $\begin{array}{c}\text { Production } \\
\text { efficiency } \\
\left(\mathrm{Kg} \mathrm{ha}^{-1} \text { day }^{-1}\right)\end{array}$ & $\begin{array}{c}\text { Land use } \\
\text { efficiency } \\
(\%)\end{array}$ & $\begin{array}{c}\% \text { sustainable } \\
\text { yield index } \\
(\mathrm{SYI})\end{array}$ \\
\hline $2012-13$ & FP & 6.76 & 35.57 & 52.05 & 63.55 \\
& IP & 11.36 & 44.54 & 69.86 & 66.88 \\
$2013-14$ & FP & 6.89 & 37.24 & 50.68 & 70.13 \\
& IP & 12.43 & 50.12 & 67.94 & 80.30 \\
$2014-15$ & FP & 6.86 & 38.11 & 49.31 & 76.63 \\
& IP & 11.66 & 48.99 & 65.20 & 95.72 \\
\hline Mean & FP & 6.83 & 36.97 & 50.68 & 70.10 \\
& IP & 11.81 & 47.88 & 67.66 & 77.63 \\
\hline
\end{tabular}

\section{Economic}

Between two crop sequences, the improved cropping pattern showed its superiority over farmers' existing pattern during three consecutive years of cropping season. On an average, gross return of the improved pattern was Tk.242105 ha ${ }^{-1}$ which was more than $73 \%$ higher than farmers' pattern of Tk.140015 ha ${ }^{-1}$ (Table 4). The production cost of the improved pattern (Tk.115343 ha ${ }^{-1}$ ) was higher than farmers' pattern (Tk.80973 ha-1) due to introduction of mungbean in fallow period, cost of fertilizer and other inputs. The gross margin was substantially higher in the improved pattern (Tk.126762 ha-1) than farmers' pattern (Tk. $59042 \mathrm{ha}^{-1}$ ). Inclusion of mungbean and improved varieties of rice in these cropping systems, increasing the system productivity fetched higher market price; thereby, increasing the gross margin. The $114 \%$ additional gross margin was achieved by adding $42 \%$ additional cost in the improved pattern. Returns per Taka invested were highest for mungbean-T. ausT. aman rice (2.10) over the farmers' pattern (1.73). 
Table 4. Cost benefit analysis of improved and farmer's existing cropping pattern at farmer's field (average of three years)

\begin{tabular}{c|c|c|c|c|c}
\hline Years & $\begin{array}{c}\text { Cropping } \\
\text { patterns }\end{array}$ & $\begin{array}{c}\text { Gross return } \\
\left(\mathrm{Tk} \mathrm{ha}^{-1}\right)\end{array}$ & $\begin{array}{c}\text { Cost of cultivation } \\
\left(\mathrm{Tk} \mathrm{ha}^{-1}\right)\end{array}$ & $\begin{array}{c}\text { Gross margin } \\
\left(\mathrm{Tk} \mathrm{ha}^{-1}\right)\end{array}$ & BCR \\
\hline $2012-13$ & FP & 138580 & 80670 & 57910 & 1.72 \\
& IP & 232880 & 115105 & 117775 & 2.02 \\
$2013-14$ & FP & 141245 & 80670 & 60575 & 1.82 \\
& IP & 254815 & 115105 & 139710 & 2.21 \\
$2014-15$ & FP & 140630 & 81580 & 59050 & 1.72 \\
& IP & 239030 & 115820 & 123210 & 2.06 \\
\hline Mean & FP & 140015 & 80973 & 59042 & 1.73 \\
& IP & 242105 & 115343 & 126762 & 2.10 \\
\hline
\end{tabular}

The costs $\left(\mathrm{Tk} \mathrm{kg}^{-1}\right)$ : rice seed (32.00), mungbean seed (150.00), and, urea (20.00), TSP (22.00) and MoP (15.00).

Among field operations, the cost of plowing was taken as Tk. 10 decimal $^{-1}$, labour cost of Tk. $300 \mathrm{~m}^{-1} \mathrm{day}^{-1}$. Gross returns included income from sale of main and by-products (Tk ka${ }^{1}$ ) of all crops; T. aus rice (19.00), T. aman rice (20.50), mungbean (70.00), stover (1.00).

\section{Conclusion}

Three years study revealed that Mungbean-T. aus-T. aman rice cropping pattern is more productive, sustainable and remunerative for medium high land under Eastern Surma Kushiyara Floodplain (AEZ 20). So, farmers of commanding area could follow Mungbean (var. BARI Mung-6)-T. aus (var. BRRI dhan48)-T. aman rice (var. Binadhan-7) cropping pattern for higher productivity and profitability as well as utilization of fallow land sustainable soil health.

\section{Acknowledgements}

Authors are gratefully acknowledged Bangladesh Agricultural Research Institute, Gazipur and Metrological Department, Sylhet for providing financial help and logistic support and weather data, respectively. Thanks to others who contributed in editing and compiling the manuscript.

\section{References}

Azad, A. K., F. A. H. Talukdar, M. A. Wahhab and M. A. Khan. 1982. Progress and prospect of jute based cropping systems research in Bangladesh. Proc. Expert Cons. Jute and Kenaf Improvement: Pp. 244-267.

Becker, M., J. K. Ladha and M. Ali. 1995. Green Manure Technology: Potential usage, limitation: a case study for low land rice. Plant and Soil 174: 181-194.

FRG. 2012. Fertilizer Recommendation Guide: published by Bangladesh Agricultural Research Council (BARC), Farmgate, Dhaka, Bangladesh. Pp-286.

Kamrozzaman, M. M., M. A. H. Khan, S. Ahmed, and A. F. M. Ruhul Quddus. 2015. On-farm evaluation of production potential and economics of Wheat-Jute-T. aman rice-based cropping system; J. Bangladesh Agril. Univ. 13(1): 93-100. 
Khan, M. A. H., M. A. Quayyum, M. I. Nazrul, N. Sultana and M. R. A. Mollah. 2005. On-farm evaluation of production potential and economics of mustard-rice based improved cropping system. J. Socio. Res. Dev. 2(1): 37-42.

Krishna, A and K.A. Reddy. 1997. Production potential and economics of different rice (Oryza sativa) - based cropping system in Andhra Pradesh. India J. of Argil. Sci. 67 (12): 551-553.

Malavia, D. D., M. P. Singh, M. M. Vyas, J. C. Patel and K. K. Kalaria. 1986. Production potential and economic feasibility of different crop sequences. Indian J. Argon. 31(1): 75-78.

McDonagh , J. F., B. Toomsan, V. Limpinuntana and K. E. Giller. 1995a. Grain legumes and green manures as pre-rice crops in Northeast Thailand. I. Legume $\mathrm{N}_{2}$-fixation, production and residual nitrogen benefits to rice. Plant and Soil 177: 111-126.

Nazrul, M. I. and M. R. Shaheb. 2012a. Potato-T. aus-T. aman: An improve and sustainable cropping pattern for fallow land utilization of Sylhet. Published by OnFarm Research Division, Bangladesh Agricultural Research Institute (BARI), Sylhet3100. Pp-24.

Nazrul, M. I. and M. R. Shaheb. 2012b. Screening of pulse crop for fallow land utilization in Sylhet region. Bangladesh Agron. J. 15(2):59-65.

Nazrul, M. I., M. R. Shaheb, M. A. H. Khan and A. S. M. M. R. Khan. 2013. On-farm evaluation of production potential and economic returns of Potato-Rice Based improved cropping system. Bangladesh J. Agril. Res. 16(2): 41-50.

Norman, M. J. T., Pearson, C. J. and Searle, P. G. E. 1984. The Ecology of Tropical Food Crops. Camb. Univ. Press.

Ram A. Jat, R. A. Dungrani, M. K. Arvadia and Kanwar L Sahrawat. 2012. Diversification of rice (Oryza sativa L.) based cropping systems for higher productivity, resource-use efficiency and economic returns in South Gujarat of India. Archives of Agronomy and Soil Science. 58(6): 561-572.

Shaheb, M. R, M. I. Nazrul, A. K. Chowdhury, M. M. R Sarker, A. S. M. Khan and J. U. Sarker. 2011. Chick pea-T. aus- T. aman: A prosperous and improved cropping pattern for Sylhet region. Published by On- Farm Research Division, Bangladesh Agricultural Research Institute (BARI), Sylhet-3100. Pp-13.

Soni, P. N and R. Kaur. 1984. Studies on production potential of different cropping systems. Indian J. Agron. 29(3): 367-78.

Tomer, S. S and A. S. Tiwari. 1990. Production potential and economics of different crop sequences. Indian J. of Agron. 35(1, 2): 30-35.

Verma, S. P and S. C. Modgal. 1983. Production potential and economics of fertilizer application as resources constraints in maize, wheat crop sequence. Himachal J. Agric. Res. 9(2): 89-92. 